\title{
Physical Characteristics of Active Packaging Based on Methyl Cellulose with The Addition of Glutaraldehyde and Klutuk Banana (Musa balbisiana Colla) Leaf Extract
}

\author{
DOI: 10.18196/pt.2019.103.130-136
}

\author{
Safinta Nurindra Rahmadhia ${ }^{1,2}$, Umar Santoso $^{2,3}$, Supriyadi $^{2,3 *}$ \\ ${ }^{1}$ Study Program of Food Technology, Faculty of Industrial Technology, Universitas Ahmad Dahlan, Yogyakarta, Indonesia \\ ${ }^{2}$ Department of Food and Agricultural Products Technology, Faculty of Agricultural Technology, Universitas Gadjah Mada, Yogyakarta, Indonesia \\ ${ }^{3}$ Center for Food and Nutrition Studies, Universitas Gadjah Mada, Jalan Teknika Utara, Barek- Bulaksumur, Yogyakarta, Indonesia \\ ${ }^{*}$ Corresponding author, email: suprif248@ugm.ac.id
}

\begin{abstract}
Klutuk banana leaf is widely used as food packaging material since it has large size and not easily torn. Many traditional packaging materials are recently abandoned, thus it is necessary to develop an active packaging having an advantage of synthetic packaging. This study aimed to create active packaging from methyl cellulose (MC) added with glutaraldehyde (GA) and Klutuk banana leaf extract (EDPK), as well as to determine its properties and antioxidants. The casting method with GA as a crosslinker and EDPK as an antioxidant agent was used to make film/active packaging. Banana Klutuk leaves were dried using cabinet dryer for 24 hours and the leaf powder was extracted using maseration method with methanol 80\%. The extract was concentrated with a rotary evaporator to be tested for its antioxidant capacity. The results showed that the film with EDPK addition exhibited dark green color. Tensile strength values increased when EDPK and GA were added at concentrations of 30 and 45\%. However, EDPK film elongation was not affected by GA addition. Addition of EDPK decreased thermal stability by $25-45^{\circ} \mathrm{C}$, whereas the addition of GA improved thermal stability by $5-25^{\circ} \mathrm{C}$. Antioxidants in banana leaf extract can migrate to 10 and $50 \%$ simulant ethanol.
\end{abstract}

Keywords: Active packaging, Antioxidant, Banana Leaf, Glutaraldehyde, Methyl Cellulose.

\section{ABSTRAK}

Daun pisang Klutuk banyak digunakan sebagai bahan pengemas makanan karena memiliki ukuran yang lebar dan tidak mudah sobek dibandingkan dengan daun pisang jenis lainnya. Dewasa ini, pengemas tradisional banyak ditinggalkan masyarakat, sehingga perlu dikembangkan suatu kemasan aktif yang memiliki keunggulan dari pengemas sintetis. Tujuan dari penelitian ini adalah membuat kemasan aktif dengan bahan utama methyl cellulose(MC) yang ditambahkan glutaraldehyde (GA) dan ekstrak daun pisang Klutuk (EDPK), kemudian dipelajari sifat fisik dan antioksidannya. Metode yang digunakan pada pembuatan film/kemasan aktif menggunakan metode casting dengan GA sebagai crosslinker dan ditambahkan EDPK sebagai bahan antioksidan. Daun pisang Klutuk dikeringkan menggunakan cabinet dryer selama 24 jam. Bubuk daun pisang diekstraksi dengan metode maserasi menggunakan methanol 80\%. Ekstrak dipekatkan dengan rotary evaporator dan dianaisa antioksidannya. Dari penelitian yang dilakukan dapat disimpulkan bahwa warna film EDPK menunjukkan warna hijau tua seiring dengan penambahan EDPK. Nilai tensil strength meningkat ketika ditambahkan EDPK dan GA pada konsentrasi 30 dan $45 \%$ namun elongation film EDPK tidak dipengaruhi oleh penambahan GA. Penambahan EDPK menurunkan stabilitas termal sekitar 25-45드. sedangkan penambahan GA dapat meningkatkan stabilitas termal sekitar 5-25 ․ . Antioksidan pada ekstrak daun pisang Klutuk dapat bermigrasi kedalam simulan etanol 10 dan 50\%. Kata Kunci: Antioksidan, Daun Pisang Klutuk, Glutaraldehydel, Kemasan Aktif, Methyl Cellulose

\section{INTRODUCTION}

Many regional foods in Indonesia use leaves such as banana leaves, teak leaves, guava leaves, "simpor" leaves, and others as packaging materials. Banana leaves are widely used as food packaging. Only a few types of banana leaves are commonly used as packaging, especially by Javanese people, including "Klutuk"-, "Kepok"-, "Raja Bandung/ Uter"- banana leaves. Food will have a certain taste when it is wrapped and steamed in banana leaves (Mohapatra et al., 2010). According to the previous study, banana leaf has antimicrobial and antioxidant activity. Banana leaf extract contains gallic acid type of catechin. Catechins are included in polyphenol group, and it is one of the antioxidant compounds (Sahaa et al., 2013). Since banana leaf extract contains antioxidant compounds, it can be used as an active compound that can be inserted into active packaging.

Traditional packaging has been largely abandoned because it is impractical and hard to find 
in the modern market. People begin to switch to plastic as a packaging. However, plastic does not contribute flavors and active compounds to packaged food. Besides, plastic is unbiodegradable, making it not environmentally friendly. Therefore, natural polymers which are substituted with extract or active compound can be used for active packaging that are environmentally friendly.

The active packaging based on methyl cellulose (MC) is widely used because it is thermo-gelated, and it has good film making properties, such as oxygen efficiency, lipid barrier, good water vapor permeability, increased tensile strength and good solubility (Ayana and Turhan, 2009; Gracia et al., 2004; Hauser et al., 2015). According to Dicastillo et al. (2016), MC is a biopolymer that has environment friendly properties. The crosslinking material that is widely used in MC-based packaging is glutaraldehyde (GA). According to Hernandez-Munoz et al. (2004), crosslinking is one method that is often used to modify water-soluble polymers to achieve the desired properties. Some characteristics of polymers can be enhanced by crosslinking, such as increased permeability, increased swelling, and mechanical properties such as tensile strength and elongation (Aiedeh et al., 2006; Dicastillo et al., 2016). GA reacts quickly with amine groups at neutral $\mathrm{pH}$, and it is more efficient than other aldehydes in terms of stability as a crosslinker thermally and chemically (Nimni et al., 1987; Okuda et al., 1991).

Active packaging is a package supplied by a compound in packaging or headspace packaging materials to improve the performance of the packaging system (Robertson, 2006). Some previous research results state that active packaging can actively respond to product changes or packaging environments, such as oxygen scavenger, $\mathrm{CO} 2$ absorbers or $\mathrm{CO} 2$ generators, ethanol emitters, ethylene absorbers, water absorbers, materials antimicrobial, flavor enhancer and photochromic (Vermeiren et al., 1999; Park et al., 2001; Kerry et al., 2006; Mahalik et al., 2010; Appendini and Hotchkiss., 2002). The natural active ingredients of maqui berry extract, chilean berry, murta fruit and leaves, L-tocopherol, tea leaf catechins and olive leaf extract have been incorporated into MC-based active packaging so that they can improve the performance of the active packaging system (Ayana and Turhan, 2009; Dicastillo et al., 2015; Dicastillo et al., 2016; Hauser et al., 2015; Noronha et al., 2014; Yu et al., 2014).

The objective of this study was to create active packaging with methyl cellulose (MC) as the main ingredient, which was added with glutaraldehyde (GA) and Klutuk banana leaf extract (EDPK), as well as to determine its properties and antioxidants. This effort is a form of packaging material development by utilizing local wisdom.

\section{MATERIALS AND METHODS}

Materials and Instruments

Klutuk banana leaves were harvested from banana orchard in Gamping, Yogyakarta. Methyl Cellulose (Sigma Aldrich, USA) and Glutaraldehyde (Merck, USA) were used for making active packaging. Several chemicals such as Polyethylene Glycol 400 (Merck, USA), 2,2-diphenyl-1-picrylhydrazyl (DPPH) (Sigma Aldrich, USA), Gallic acid (Sigma Aldrich, USA), Quercetin (Sigma Aldrich, USA), and Folin Ciocalteu (Merck, Germany) were prepared for further analysis.

The apparatus used were Cabinet dryer (EYELA NDS-601D; Japan), Rotary vacuum evaporator (IKA RV 06-ML 1-B), UV-VIS Spectrophotometer (Spectronic 200), Chromameter (Konika Minolta CR-400), Universal Testing Machine (Zwick ZO.5; USA), Thermogravimetric Analysis (Diamond TG / DTA Perkin Elmer). 


\section{Klutuk Banana Leaf Extraction}

The extraction of Klutuk banana leaves was carried out based on the method by Fitriani (2016). Banana leaves with good quality were taken (the leaves are green, not torn, clean and undamaged) from the second and third stems from the top of the trees. Banana leaves were washed using tap water and cut into $3 \times 4 \mathrm{~cm}$ using scissors. Banana leaves were dried using a cabinet dryer at $50^{\circ} \mathrm{C}$ for 24 hours then mashed with a blender. A $100 \mathrm{~g}$ Klutuk banana leaf powder was soaked in $800 \mathrm{ml}$ of $80 \%$ methanol for 48 hours at room temperature and filtered using filter cloth and Whatman paper number 41 . Then, the supernatant was concentrated with a rotary vacuum evaporator at $40^{\circ} \mathrm{C}$.

\section{Active Packaging Preparation}

Active packaging was prepared using the film casting method based on the method of Dicastillo et al. (2015 and 2016) with modifications. The main material used was methyl cellulose. A $0.75 \mathrm{~g}$ of methyl cellulose was dissolved in $100 \mathrm{ml}$ of $70 \%$ ethanol at $70 \mathrm{oC}$ for 1 hour. Then glutaraldehyde 15,30 and $45 \%(\mathrm{w} / \mathrm{w})$ and $1 \mathrm{M} \mathrm{HCl}$ were added to reach $\mathrm{pH} 3$ and then cooled. After the temperature of the solution reached 40 o C, 50,000 ppm of Klutuk banana leaf extract $(5,10$ and $15 \%(\mathrm{v} / \mathrm{v}))$ and polyethylene glycol 400 (PEG 400) 25\% (w/w) were added. The solution was poured in a glass tray $15 \times 21 \times 2 \mathrm{~cm}$ and put into a cabinet dryer at $50 \mathrm{o}$ $\mathrm{C}$ for 12 hours. The film obtained is called EDPK film (Klutuk banana leaf extract).

\section{Characterization of Active Packaging Optical Properties}

The film color was determined using chromameter (Konika Minolta CR-400). The film was placed on top of the plate reader, then placed on the top of the chromameter. The plate reader was shot with light on the tool used. The color was expressed in L (lightness), a (appearance), and b (blueness). The color measurement of the film was carried out three times.

\section{Mechanical Properties}

Mechanical analysis of the film included tensile strength and elongation with Universal Testing Machine (Zwick ZO.5; USA). The specimen was placed on the center of the plate until it was locked. The speed was set to $10 \mathrm{~mm} / \mathrm{min}$ then the machine was turned on. After the sample was broken, the machine stopped and graphical data appeared on the monitor. Three specimens were used to determine the average of mechanical parameters.

\section{Thermogravimetric Analysis (TGA)}

Thermogravimetric analysis was tested using TG/DTA (Diamond TG/DTA; Perkin Elmer). The sample was heated at a temperature range from 30 to $600^{\circ} \mathrm{C}$ with an increase of $10^{\circ} \mathrm{C} /$ minute to determine the evaporation process of volatile components and or degradation in the sample. For samples in the form of sheets or chunks, particle size reduction was carried out by measuring the cross-sectional area of the pan sample.

\section{Release Studies of Active Packaging}

A study of release on active packaging was based on Dicastillo et al. (2015). The films were soaked in food simulants. Two types of food simulants were used, namely $10 \%$ ethanol (a) as a simulation of aqueous foods and $50 \%$ ethanol (b) as simulation for fatty foods. The film was cut into $3 \mathrm{~cm} 2$ and placed in a vial than added with $5 \mathrm{ml}$ simulant a and b. Migration studies was carried out at $40^{\circ} \mathrm{C}$. Food simulants a and $\mathrm{b}$ were taken periodically $0,2,4,6,8,12,24,48$, and 72 hours. Analysis of antioxidant activity was performed using DPPH method to find out the active components of the released film into food simulants. 


\section{Data Analysis}

The data obtained were statistically analyzed with IBM SPSS Statistics 20 and MS Excel 2007. Two-way ANOVA was used to compare the effect of Klutuk banana leaf extract and glutaraldehyde. The differences between treatments were tested using Duncan's Multiple Range Test (DMRT) with $\mathrm{p}<0.05$.

\section{RESULTS AND DISCUSSION}

\section{Optical Properties}

EDPK films with higher concentration of Klutuk banana leaf extract showed increasingly darker , more red and more blue color. The result showed that the $L$ and $b$ value decreased significantly with the increase of Klutuk banana leaf extract (Table 1). Meanwhile, a value increased significantly with the increase of Klutuk banana leaf extract. Overall,

Table 1. The color of methyl cellulose-based film with the addition of glutaraldehyde and Klutuk banana leaf extract in various combinations

\begin{tabular}{lccc}
\hline \multirow{2}{*}{ Sample } & \multicolumn{3}{c}{ Color } \\
\cline { 2 - 4 } & $* \mathrm{*}$ & *a & *b \\
\hline DP5_GA0 & $66.51 \pm 0.14^{\mathrm{c} 1}$ & $2.45 \pm 0.03^{\mathrm{a} 1}$ & $61.46 \pm 0.09^{\mathrm{c} 2}$ \\
DP5_GA15 & $65.44 \pm 0.48^{\mathrm{c} 1}$ & $2.23 \pm 0.04^{\mathrm{a} 2}$ & $65.96 \pm 0.19^{\mathrm{c} 3}$ \\
DP5_GA30 & $67.86 \pm 1.13^{\mathrm{c} 2}$ & $2.51 \pm 0.06^{\mathrm{a} 3}$ & $65.36 \pm 0.15^{\mathrm{c} 3}$ \\
DP5_GA45 & $66.98 \pm 0.42^{\mathrm{c3}}$ & $2.36 \pm 0.05^{\mathrm{a} 4}$ & $61.38 \pm 0.46^{\mathrm{c} 1}$ \\
& & & \\
DP10_GA0 & $55.39 \pm 0.42^{\mathrm{b} 1}$ & $7.35 \pm 0.05^{\mathrm{b} 1}$ & $51.42 \pm 0.17^{\mathrm{b} 2}$ \\
DP10_GA15 & $55.42 \pm 0.33^{\mathrm{b} 1}$ & $7.47 \pm 0.02^{\mathrm{b} 2}$ & $50.24 \pm 0.43^{\mathrm{b} 23}$ \\
DP10_GA30 & $55.12 \pm 0.10^{\mathrm{b} 2}$ & $7.32 \pm 0.06^{\mathrm{b3}}$ & $49.45 \pm 0.12^{\mathrm{b3}}$ \\
DP10_GA45 & $56.64 \pm 0.08^{\mathrm{b3}}$ & $7.87 \pm 0.07^{\mathrm{b} 4}$ & $48.39 \pm 0.18^{\mathrm{b} 1}$ \\
& & & \\
DP15_GA0 & $44.56 \pm 0.24^{\mathrm{a} 1}$ & $9.10 \pm 0.01^{\mathrm{c} 1}$ & $43.79 \pm 0.22^{\mathrm{a} 2}$ \\
DP15_GA15 & $44.76 \pm 0.06^{\mathrm{a} 1}$ & $9.58 \pm 0.06^{\mathrm{c} 2}$ & $41.53 \pm 0.09^{\mathrm{a} 23}$ \\
DP15_GA30 & $45.01 \pm 0.64^{\mathrm{a} 2}$ & $9.87 \pm 0.06^{\mathrm{c} 3}$ & $43.47 \pm 0.95^{\mathrm{a} 3}$ \\
DP15_GA45 & $46.38 \pm 0.35^{\mathrm{a} 3}$ & $9.74 \pm 0.05^{\mathrm{c} 4}$ & $42.90 \pm 0.52^{\mathrm{a} 1}$ \\
\hline
\end{tabular}

Remarks: Values followed by the same letters in the same column are not significantly different as affected by Klutuk banana leaf extract (DP) $(p<0.05)$. Values followed by the same number codes in the same column are not significantly different as affected by glutaraldehyde (GA) $(p<0.05)$. DP5, DP10 and DP 15 are the addition of Klutuk banana leaf extract as many as 5, 10 and $15 \%$. $\mathrm{GA0}, \mathrm{GA} 15, \mathrm{GA} 30$ and GA45 are the addition of glutaraldehyde by $0,15,30$ and $45 \%$.
EDPK films had a green to dark green color because Klutuk banana leaf extract was greenish black.

The dark color of the EDPK film can be an advantage. Also, dark colors of the packaging can protect food from light causing damage, one of which is oxidation. According to Choe and Min (2006), oxidation begins with a catalyst reaction involving heat, light and oxygen. Oxidation will result in the formation of free radicals which release hydrogen. Haile et al. (2013) reported that cooked ham wrapped with foil and kept in light showed higher discoloration than cooked ham wrapped with foil and kept in dark. With the presence of green color on the film, the EDPK film can protect packaged foods from being exposed to light so that it can reduce the formation of free radicals.

\section{Mechanical properties}

The film with the addition of $10 \%$ Klutuk banana leaf extract had a significantly higher elongation at break (EB) than the film added with 5 and $15 \%$ Klutuk banana leaf extract (Table 2). In overall, the addition of glutaraldehyde (GA) significantly increased tensile strength (TS) but had no effect on the EB. Besides GA, plasticizers also had an important role to play in the mechanical properties of film or packaging. TS and EB in a film are also influenced by the thickness of the film (Akhtar et al., 2012).

The increase in TS is in line with the research by Park and Ruckeinstein (2001) which reported that TS on methyl cellulose (MC) increased with the increase of $\mathrm{GA}$ and $\mathrm{HCl}$ concentration. On the contrary, the value of EB decreased. It can be explained that the addition of GA increases the network structure so the polymer chain mobility decreases. Therefore, material that experiences crossing becomes rigid. However, if the GA concentration increases to the maximum concentration, GA can function as a plasticizer which causes softening 
Tabel 2. The mechanical properties of methyl cellulose-based films with the addition of glutaraldehyde and Klutuk banana leaf extract in various combinations

\begin{tabular}{lcc}
\hline Sample & Tensil strength $\left(\mathrm{N} / \mathrm{mm}^{2}\right)$ & Elongation at break $(\%)$ \\
\hline DP5_GA0 & $12.75 \pm 0.86^{\mathrm{b} 1}$ & $61.59 \pm 4.97^{\mathrm{a} 1}$ \\
DP5_GA15 & $13.60 \pm 0.18^{\mathrm{b} 2}$ & $59.90 \pm 3.98^{\mathrm{a} 1}$ \\
DP5_GA30 & $15.73 \pm 0.58^{\mathrm{b}}$ & $52.49 \pm 4.67^{\mathrm{a} 1}$ \\
DP5_GA45 & $16.46 \pm 0.37^{\mathrm{b3}}$ & $56.70 \pm 3.68^{\mathrm{a} 1}$ \\
& & \\
DP10_GA0 & $16.23 \pm 0.67^{\mathrm{c} 1}$ & $59.60 \pm 6.04^{\mathrm{b} 1}$ \\
DP10_GA15 & $15.80 \pm 1.62^{\mathrm{c}}$ & $75.91 \pm 5.29^{\mathrm{b} 1}$ \\
DP10_GA30 & $15.35 \pm 0.87^{\mathrm{c3}}$ & $68.28 \pm 3.94^{\mathrm{b} 1}$ \\
DP10_GA45 & $16.35 \pm 0.89^{\mathrm{c3}}$ & $65.46 \pm 3.82^{\mathrm{b} 1}$ \\
& & \\
DP15_GA0 & $4.73 \pm 0.13^{\mathrm{a} 1}$ & $65.82 \pm 1.96^{\mathrm{a} 1}$ \\
DP15_GA15 & $8.16 \pm 0.70^{\mathrm{a} 2}$ & $45.44 \pm 3.37^{\mathrm{a} 1}$ \\
DP15_GA30 & $15.63 \pm 0.24^{\mathrm{a}}$ & $66.41 \pm 4.37^{\mathrm{a} 1}$ \\
DP15_GA45 & $13.78 \pm 0.68^{\mathrm{a} 3}$ & $64.23 \pm 5.17^{\mathrm{a} 1}$ \\
\hline
\end{tabular}

Remarks: Values followed by the same letters in the same column are not significantly different as affected by Klutuk banana leaf extract (DP) $(p<0.05)$. Values followed by the same number codes in the same column are not significantly different as affected by glutaraldehyde (GA) $(p<0.05)$. DP5, DP10 and DP 15 are the addition of Klutuk banana leaf extract as many as 5, 10 and $15 \%$. $\mathrm{GA} 0, \mathrm{GA15}, \mathrm{GA} 30$ and GA45 are the addition of glutaraldehyde by $0,15,30$ and $45 \%$.

of the crossed film. The higher the excess GA, the higher the plasticizing effect. Also, an increase in TS value was caused by the formation of a more stable network because of crosslinking among MC, EDPK and GA as a crosslinker agent. The increase in TS and decrease in EB indicate a relationship between polymer chains and GA (Benbettaieb et al., 2015; Rimdusit et al., 2008).

\section{Thermogravimetric Analysis (TGA)}

The thermogram in Figure 1 shows the maximum decomposition in the sample at temperatures of $220,225,175$ and $200^{\circ} \mathrm{C}$ for DP5_GA0, D5_GA45, DP15_GA0 and DP15_GA45. Based on Figure 1, it can be stated that the addition of Klutuk banana leaf extract could lower the thermal stability by $25-45^{\circ} \mathrm{C}$, while the addition of GA could increase thermal stability around $5-25^{\circ} \mathrm{C}$. A decrease in thermal stability caused the film to become brittle when heated at high temperatures.
When compared with the research by Dicastillo et al. (2016), the maximum decomposition value in EDPK films shows a lower value. Thermograms in the film owned by Dicastillo et al. (2016) showed a maximum decomposition value at temperatures around 361oC. The low thermal decomposition of MC-based films with the addition of GA and Klutuk banana leaf extract was caused by the crosslinking between the three components (MC, GA, and Klutuk banana leaf extract) which did not produce new bonds which thermally having better heat resistance MC network.

\section{Release Studies of Active Packaging}

Overall, the antioxidant activity of EDPK films has the same release profile, which increases at 2 hours and will be constant or will decrease at 72 hours (Figure 2). Research on antioxidant release by Calatayud et al. (2013), Dicastillo et al. (2011) and Dicastillo et al. (2015) showed an antioxidant release curve in the form of the maximum exponential curve profile, although the samples had a different area, kinetics and GA content. In line with the research of Calatayud et al. (2013), Dicastillo et al. (2011) and Dicastillo et al. (2015), in this study, the resulting curve is also a maximum exponential curve.

The antioxidant release was influenced by the presence of MC crosslinking with EDPK and GA as a crosslinker agent. In the study of Dicastillo et al. (2015), the release of phenolic compounds in food simulations was slightly influenced by interactions between MC, GA and extract of maqui berry. Balaguer et al. (2011), Khalil et al. (2015), Mi et al. (2006) and Yu et al. (2014) stated that natural compounds from plants such as cinnamaldehyde, eugenol, citric acid, geniposidic acid and catechins from green tea extract may act as crosslinking additives.

Figure 2 shows that the DP15_GA0 film has the highest antioxidant activity on $10 \%$ and $50 \%$ etha- 


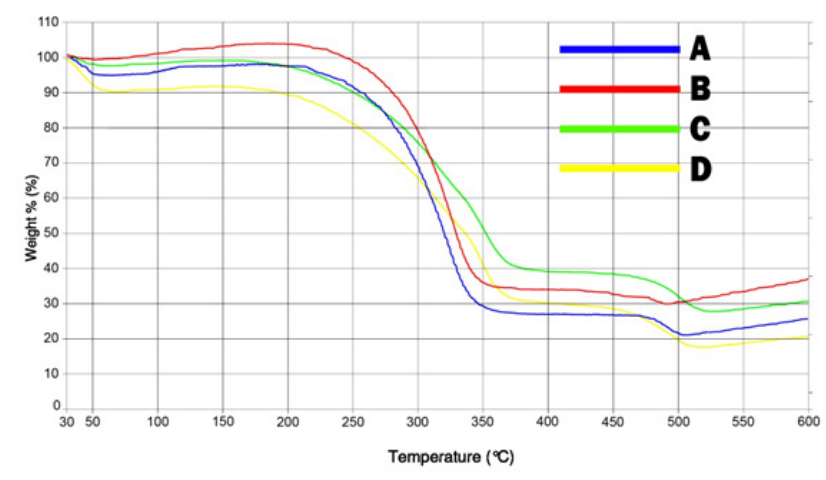

Figure 1. TGA in methyl celluloce-based films with the addition of glutaraldehyde and Klutuk banana leaf extract. $(A)$ DP5_GA0 (B) DP5_GA45 (C) DP15_GA0 (D) DP15_ GA45. (DP5 and DP 15 are the addition of Klutuk banana leaf extract 5 and 15\%. GA0 and GA45 are the addition of glutaraldehyde 0 and $45 \%$ ).
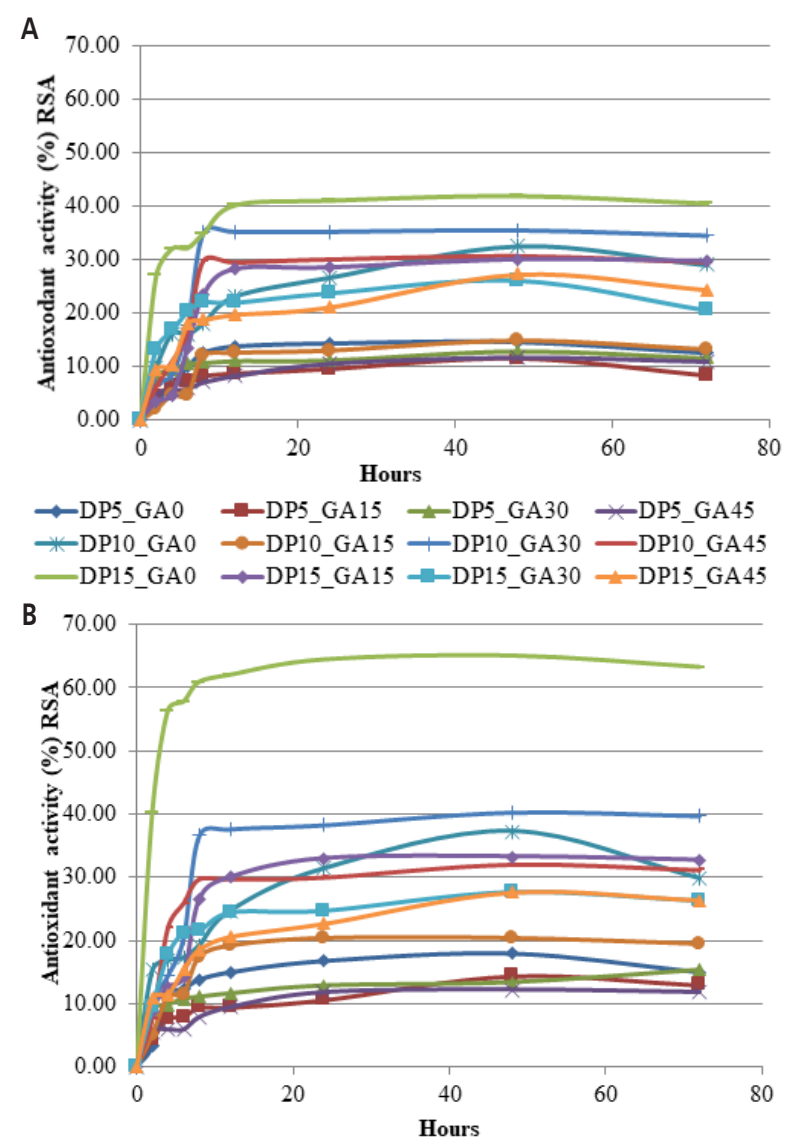

Figure 2. Release of antioxidants in EDPK films. (A) EtOH Simulations 10\% (B) EtOH Simulations 50\%. (DP 5, 10 and 15 are the addition of Klutuk banana leaf extract 5,10 and $15 \%$. GAO, 15, 30 and 45 are the addition of glutaraldehyde $0,15,30$ and $45 \%$ ). nol simulations. By decreasing the concentration of GA, the active component of Klutuk banana leaf extract cannot react with the $\mathrm{MC}$ polymer chain to form a crosslinking. Therefore, EDPK can release into food simulation optimally.

\section{CONCLUSIONS}

This study provides a method to prepare active packaging with methyl cellulose (MC) as the main ingredient, which was added with glutaraldehyde (GA) and Klutuk banana leaf extract (EDPK). The active packaging was also then studied for its properties and antioxidants. The result showed that the addition of Klutuk banana leaf extract caused the color of the film to be green to dark green. Films with the addition of Klutuk banana leaf extract and GA caused the film to be stronger, marked by an increase in TS and EB. The heat resistance of EDPK films was low so that the film became easily brittle when heated. Klutuk banana leaf extract added to MC-based active packaging can migrate into food simulations, therefore EDPK films may act as antioxidants.

\section{ACKNOWLEDGMENTS}

The authors would like to thank Ministry of Research, Technology and Higher Education (Kemenristek Dikti) for funding this research through the Penelitian Unggulan Perguruan Tinggi (PUPT) 2016 grant program.

\section{REFERENCES}

Aiedeh, K. M., Taha, M. O., Al-Hiari, Y., Bustanji, Y., and Alkhatib, H. S. (2006). Effect of lonic Crosslinking on The Drug Release Properties of Chitosan Diacetate Matrices. Journal of Pharmaceutical Sciences, 96: 38-43.

Akhtar, M.J., Jacquot, M., Jasniewski, J., Jacquot, C., Imran, M., and Jamshidian, M. (2012). Antioxidant Capacity and Light-aging Study of HPMC Films Functionalized with Natural Plant Extract. Carbohydrate Polymers, 89: 1150-1158.

Appendini, P. and Hotchkiss, J.H. (2002). Review of Antimicrobial Food Packaging. Innovative Food Science and Emerging Technologies, 3 (2): 113-126. 
Ayana, B. and Turhan, K.N. (2009). Use of Antimocrobial Methylcellulose Films to Control Staphylococcus aureus During Storage of Kasar Cheese. Packaging Technologi and Science, 22: 461-469.

Balaguer, M. P., Gomez-Estaca, J., Gavara, R., and Hernandez-Munoz, P. (2011). Biochemical Properties of Bioplastics Made From Wheat Gliadins Cross-linked With Cinnamaldehyde. Journal of Agricultural and Food Chemistry, 59: 13212-13220.

Calatayud, M., Lopez de Dicastillo, C., Lopez-Carballo, G., Velez, D.,Hernandez-Munoz, P., and Gavara, R. (2013). Active Films Based on Cocoa Extract With Antioxidant, Antimicrobial and Biological Applications. Food Chemistry, 139: 51-58.

Choe, E. and Min, D.B. (2006). Mechanism and Factors For Edible Oil Oxidation. Comprehensive Reviews in Food Science and Food Savety, 5 : 1-5.

Dicastillo, C.L., Nerin, C., Alfaro, P., Catala, R., Gavara, R., dan Hernandez-Munoz, P. (2011). Development of New Antioxidant Active Packaging Film Based on EVOH and Green tea Extract. Journal of Agricultural and Food Chemistry, 53: 7832-7840.

Dicastillo, C.L., Rodriguez, F., Guarda, A., and Galotto, M.J. (2015). Antioxidant Films Based on Cross-linked Methyl Cellulose and Native Chilean Berry For Food Packaging Applications. Journal of Carbohydrate Polymers, 136: 1052-1060.

Dicastillo, C.L., Bustos, F., Guarda, A., and Galotto, M.J. (2016). Crosslinked Methyl Cellulose Films with Murta Fruit Extract for Antioxidant and Antimicrobial Active Food Packaging. Journal of Food Hydrocolloids, 60: 335-344.

Fitriani, V. (2016). Tesis, Karakter Fisik dan Kimia serta Identifikasi Senyawa Bioaktif dari Daun Pisang Klutuk (Musa bracycarpa) Sebagai Bahan Pengemas Makanan. Fakultas Teknologi Pertanian, Universitas Gadjah Mada Yogyakarta.

Garcia, M.A., Pinotti, A., Martino, M.N., and Zaritzky, N.E. (2004). Characterization of Composite Hydrocolloids Films. Journal of Carbohydrate Polymers, 56: 339-345.

Haile, D.M., De Smet, S., Claeys, E., and Vossen, E. (2013). Effect of Light, Packaging Condition and Dark Storage Durations on Colour and Lipid Oxidative Stability of Cooked Ham. Journal Food Science Technology, 50 (2): 239 - 247.

Hauser, C., Penaloza, A., Guarda, A., Galotto, M.J., Bruna, J.E., and Rodriguez, F.J. (2015). Development of an Active Packaging Film Based on a Methylcellulose Coating Containing Murta (Ugni molinae Tutcz) leaf Extract). Food Bioprocess Technology, 9: 298-307.

Hernandez-Munos, P., Villalobos, R., and Chiralt, A. (2004). Effect of Cross-linking Using Aldehydes on Properties of Glutenin-rich Films. Food Hydrocolloids, 18: 403-411.

Kerry, J.P., O'Grandy, M.N., and Hogan, S.A. (2006). Past current and Potential Utilisation of Active and Intelligent Packaging Systems for meat and Muscle-based Product. A review: Meat Science, 74: 113-130.
Khalil, A. A., Deraz, S. F., Elrahman, S. A., and El-Fawal, G. (2015). Enhancement of Mechanical Properties, Microstructure, and Antimicrobial Activities of Zein Films Cross-linked Using Succinic Anhydride, Eugenol and Citric Acid. Preparative Biochemistry and Biotechnology, 45: 551-567.

Mahalik, N.P., Arun, N., and Nambiar. (2010). Trends in Food Packaging and Manufacturing Systems and technology. Trends in Food Science and Technology, 21: 117-128.

Mi, F. L., Huang, C. T., Liang, H. F., Chen, M. C., Chiu, Y. L., and Chen, C. H. (2006). Physicochemical, Antimicrobial, and Cytotoxic Characteristics of a Chitosan Film Cross-linked by a Naturally Occurring Cross-linking Agent, Aglycone Geniposidic Acid. Journal of Agricultural and Food Chemistry, 54: 3290-3296.

Mohapatra, D., Mishra, S., and Sutar, N. (2010). Banana and its By-product utilisation: an overview. Journal of Scientific and Industrial Research. 69: 323-329.

Nimni, M.E., Cheung, D., Strates, B., Kodama, M., and Sheikh, K. (1987). Chemically Modified Collagen: A Natural Biomaterial for Tissue Replacement. Journal Biomedicine Material, 21: 741-771.

Noronha, C.M., Carvalho, S.M., Lino, R.C., and Barreto, P.L.M. (2014). Characterization of Antioxidant Methylcellulose Film Incorporated with $\alpha$-Tocopherol Nanocapsules. Food Chemistry, 159: 529-535.

Okuda, K., Urabe, I., Yamada, Y., and Okada, H. (1991). Reactions of Glutaraldehyde With Amino and Thiol Compounds. Juornal Fermentation Bioengineering, 71: 100-105.

Park, J.S. and Ruckenstein, E. (2001). Viscoelastic Properties of Plasticized Methylcellulose and Chemically Crosslinked Methylcellulose. Journal Carbohydrat Polymer, 46: 373-381.

Rimdusit, S., Somsaeng, K., Kewsuwan, P., Jubsilp, C., and Tiptipakorn, S. (2008). Biodegradability and Property Characterization of Methyl Cellulose: Effect of Nanocompositing and Chemical Crosslingking. Carbohydrate Polymers, 72: 444 - 445.

Robertson, G. L. (2006). Active and intelligent packaging. In food packaging: principles and practice 2nd ed. CRC Press, Boca Raton, Fl.

Sahaa, R.K., Srijan A., Syed Sohidul H.S., and Priyanka R. (2013). Medicinal activities of the leaves of Musa sapientum var. sylvesteris in vitro. Asian Pacific Journal of Tropical Biomedicine, 3: 476-482.

Vermeiren, L., Devlieghree, F., and Debevere, J. (1999). Evaluation of Meat Born Lactic Acid Bacteria as Protective Cultures for the Biopreservation of Cooked Meat Product. International Journal of Food Microbiology, 96: 149-164.

Yu, S., Tsai, M., Lin, B., Lin, C., and Mi, F. (2014). Tea Catechins-crosslinked ethylcellulose Active Films For Inhibition of Light Irradiation and Lipid Peroxidation Induced $\beta$-carotene Degradation. Journal Food Hydrocolloids, 44: 491-505. 